\title{
THE INTRODUCTION INTO PUERTO RICO OF LARRA AME- RICANA SAUSSURE, A SPECIFIC PARASITE OF THE "CHANGA", OR PUERTO RICAN MOLE-CRICKET, SCAPTERISCUS VICINUS SCUDDER
}

\author{
By George N. Wolcott, Entomologist, \\ Agricultural Experiment Station, Río Piedras, $P$. $R$.
}

For many years young tobacco plants in Puerto Rico have suffered from the attack of an insect called by the growers the "changa". Its scientific name is Scapteriscus vicimus Scudder, and, altho it is not a native insect, but, merely due to the fact that it appears to be more abundant and to cause more damage in Puerto Rico, it has ordinarily been known elsewhere as the Puerto Rican mole-cricket. (fig. 1.)

The changa occurs mostly in light sandy soils, thru which it can readily burrow with its powerful shovel-shaped front legs. During dry weather it remains at considerable depths in the soil, but during wet weather it comes up, making mole-like burrows just below the surface, feeding on the tender centers of the stalks of whatever young plants may happen to be there. It does not confine its attack to tobacco; it merely happens that the best tobacco soils are also the light sandy soils best adapted to the changa. When such soils are planted to sugar-cane, the changa attacks the young cane shoot quite as readily, and the presence of the changa makes vegetable growing practically impossible in many localities where otherwise it might be a profitable practise.

The changa ean be, and is, artificially controlled. Many years ago tobacco growers learned that by wrapping each young transplanted tobacco plant in a broad, tough leaf of the mamey tree, Mammea americana L., it would be protected against attack by the mole-cricket until it had grown sufficiently large and tough to be no longer subject to injury. Cane-growers learned that, instead of placing the cane "seed" piece horizontally in the ground and lightly burying it, if stuck in at an angle, roots would start from the lower end deep in the soil, and the upper eyes would send out shoots above the surface of the soil, out of reach of the attack of the changa. Some vegetables can be protected by the method used for young tobacco plants; others can not be grown in "changa" soils, and their cultivation is no longer attempted there. It should be es- 
194 THE JOURNAL OF AGRICULTURE OF THE UNIVERSITY OF $\mathbb{E}$. $\mathbb{a}$.

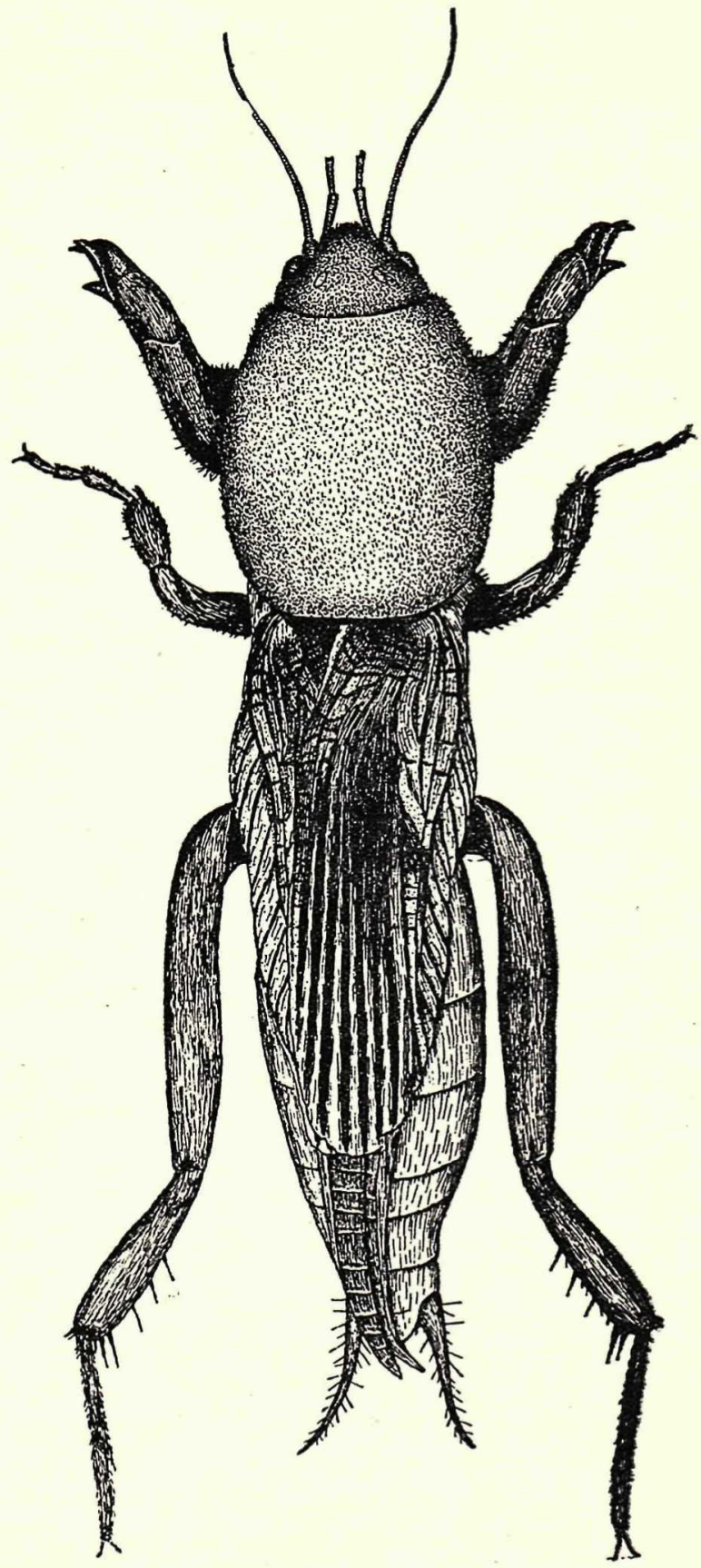

FIG. 1. The "Changa", or Puerto Rican MoleCricket, Scapteriscus vicinus Scudder, dorsal aspect. Six times natural size. (Drawn by F. Seín.) 
pecially noted, however, that these methods of preventing changa injury do not kill the pest, or even tend to reduce its numbers; they merely protect individual plants from attack at that time, and must be repeated for each succeeding crop. Indeed, while reasonably well adapted to small scale cultivation in some tobacco regions, they quickly tend to exhaust all possible supplies of fresh mamey leaves for rapidly expanding, large scale plantation production.

A positive method for destroying the changa (2 and 6), consists in the application around each tobacco plant, as set out in the field, of a ring of wheat flour and Paris green, the mixture containing twenty to fifty times as much bait as poison. This poison bait is also applicable for other crops, when distributed as lumps in the prepared field before the crop is planted. The wheat flour proves to be more attractive to the insect than any green vegetation, and is promptly eaten in such quantities that the admixed poison causes death. Because of its effiectiveness in ensuring an even stand of tobacco, and despite the very considerable expense involved, this method is in extensive use in Puerto Rico at the present time. No other method suggested even approaches it in value. Manufacturers of aluminum foil suggested that their product might prove more desirable than mamey leaves, but the changa promptly burrows thru any thickness of foil which can be readily wrapped around the roots of a seedling, and also, the foil does not rot and naturally disappear, as do the mamey leaves, when the tougher and older tobacco plant no longer needs protection. Nor do suggested improvements in the Paris green-flour mixture appear to be applicable in Puerto Rico, where the original formula is still universally used. Indeed, the sole objections to its use are on the basis of cost and trouble of application.

Naturally, the control of the changa by natural means has repeatedly been suggested, but the birds which are large enough to be effective (10), are scarce or non-existent in the thickly settled regions where tobacco is grown. The large ground lizard, Ameiva exsul Cope, which also feeds on the changa (14), is almost equally scarce where its presence would be of economic value. Much was expected of the giant Surinam toad, for the changa is more or less comparable in size, terrestrial habits and clumsiness to the May beetle, yet at the time when the toad was most abundant and was most effective in rapidly reducing the numbers of the May beetle, the changa formed but an insignificant fraction (only 2.4 per cent). of its food (7), and the proportion has not since been increased (15). 
The scarcity, or comparative inefficiency in the control of the changa, of all of these larger predators does not by any means eliminate all possibilities of natural control. The search abroad for a specific insect parasitic only on Puerto Rican white grubs was fundamentally hopeless because the local species are endemic and present nowhere else. But the Puerto Rican mole-cricket is unquestionably an introducted insect, as many of the older tobaceo growers could remember a time when it was not present to trouble them. Tradition indicates its appearance after the distribution of a shipment of Peruvian guano followed by the destruction by hurricane of most of the large birds which might have consumed these first few introduced individuals. It is not mentioned by Ledru (8), and Busck (3) notes that Dr. Augustin Stahl, the first Puerto Rican naturalist, told him that "it was a comparatively new insect in Porto Rico, having been introduced within his recollection." Its subsequent abundance in Puerto Rico unquestionably indicates that it has here escaped from its effective natural enemies, and that a search for them abroad might furnish the key to its control in Puerto Rico.

The establishment of the Board of Commissioners of Agriculture in 1911 made possible the first attempt at such a search. Mr. Patrico Cardín, recently graduated from Massachussets Agricultural College and promptly appointed Entomologist at the Experiment Station at Santiago de las Vegas, Cuba, had indeed reported such a specific parasite (4), and the writer, at that time employed by the Board in the collection and shipment of parasites of white grubs, was sent to Cuba to investigate. The sole basis for Cardín's statement was a single cocoon which he had picked up in a field being plowed, from which the Tiphia wasp had emerged, but in the silken network of threads on the outside of which was still entangled what he supposed to be the skeletal remains of a changa. A more critical examination indicated that what he supposed to be the burrowing forelegs of a changa were in fact the jaws of a white grub.

To more securely establish the actual occurrence of the molecricket in Cuba, previously recorded by Cook (5) as being present at Santiago de las Vegas, but of which no specimens remained in the collection, Cardin organized an expedition from the tobacco center of San Juan y Martínez on one of the holidays when he was. free to be absent from his office in the Experiment Station. The imposing cavalcade, starting long before daybreak, sent out severaI messengers explaining the object of our search, but it was not until nearly noon, as we were feasting on roast pork and other native 
dishes in the shade of a clump of royal palms grouped around a spring, that we were interrupted by an excited and shouting rider bearing a single but unquestionable mole-cricket. Somewhat crestfallen at the reward of a $\$ 5$ bill, he was only partially satisfied when assured that this was the equivalent of the solid silver dollars which he had anticipated. What became of this dearly obtained specimen is uncertain, for it has not recently been found in the collections in Cuba, Puerto Rico or at Washington. The difficulty of obtaining it, however, coupled with the youthfulness and inexperience of the writer, precluded the further prosecution of a search for its possible parasite at that time.

The erroneousness of Cardín's original observation should not obscure the fact that true parasites of mole-crickets do occur in various parts of the world. Possibly the best known is Larra luzonensis Rohwer, which was discovered in 1917 in the Philippine Islands by Mr. F. X. Williams of the Hawaiian Sugar Producers' Association Experiment Station when he was searching for a parasite of Gryllotalpa africana P. B. (11). This mole-cricket, accidentally introduced into Hawaii, was a serious pest of sugar-cane there until Mr. C. E. Pemberton brought cocoons of the wasp from the Philippines to Hawaii, and reared and successfully established the parasite there (12). Each parasite of each species of molecricket is specific for that kind of mole-cricket only, thus at once indicating the uselessness of attempting the introduction into Puerto Rico for the control of the changa of the wasp which has been so effective in the control of the mole-cricket in Hawaii. Not only are they different species, the two mole-crickets are in different genera, and hopelessly unlike from the standpoint of their parasites.

The logical place to commence the search for a desired parasite is in a country with a similar climate, where the identical host is known to be present, but, presumably due to its parasite, not abundant. In every way, Cuba appeared to be the most desirable place for commencing a search for a parasite of Scapteriscus vicinus Scudder, the "changa" of Puerto Rico. As tentative plans were being made however, the Entomologist at present at the Experiment Station at Santiago de las Vegas, Mr. S. C. Bruner, sent word that a recent determination of all the mole-cricket specimens in the Station collection by Mr. J. A. G. Rehn, of the Philadelphia Academy of Natural Sciences, the recognized specialist in this group, showed them to be Gryllotalpa hexadactyla Perty (fig. 2), and that the Puerto Rican changa apparently did not occur in Cuba (9). There is no record of a 


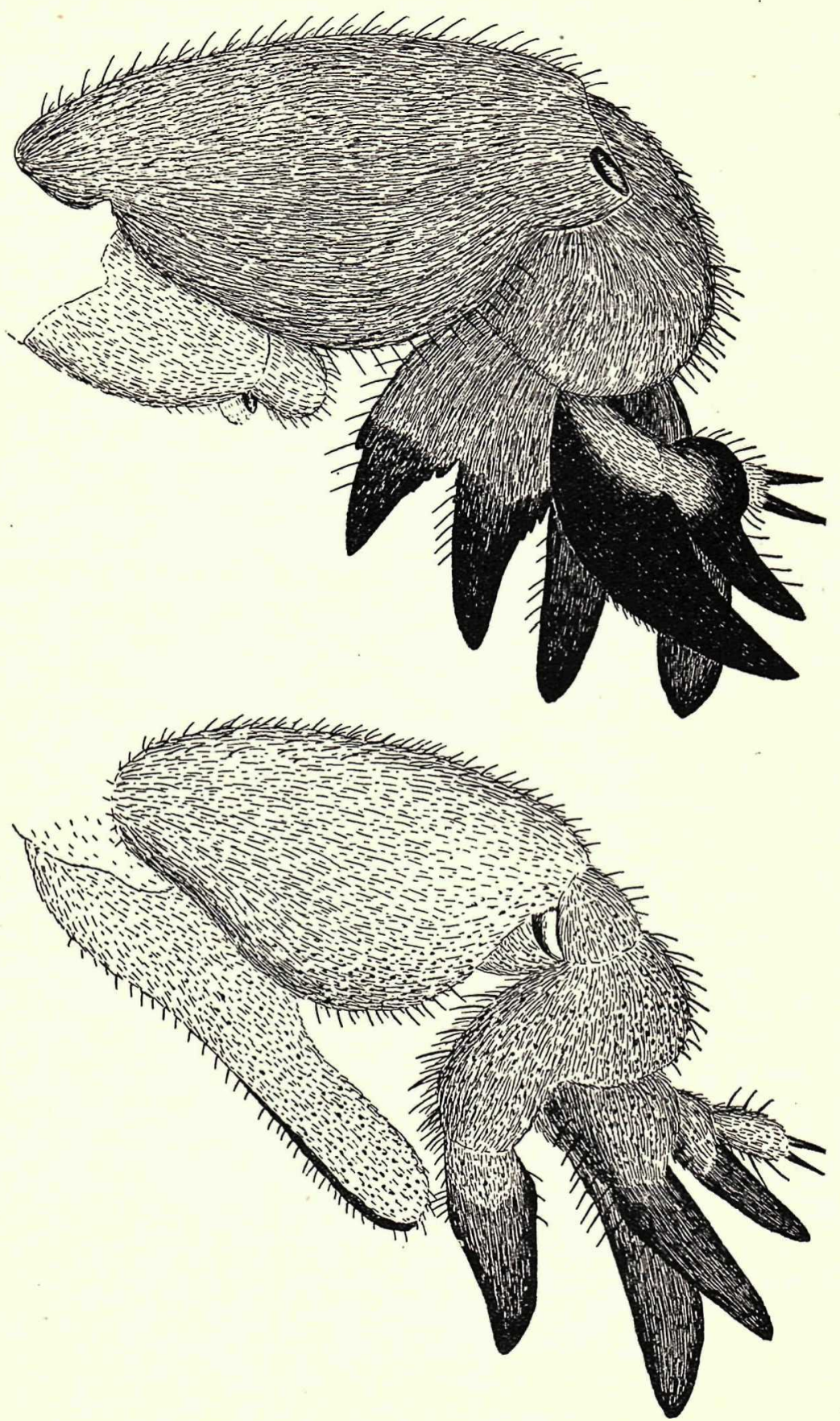

FIG. 2.-Foreleg of the West Indian Mole-Cricket, Gryllotalpa hexadactyla Perty (above), for comparison with that of the Puerto Rican "Changa", Scapteriscus vicinus Scudder (below). (Drawn by F. Seín.) 
mole-cricket in Jamaica, and those from Hispaniola were open to doubt. Concerning the Lesser Antilles little definite information was available, but in Trinidad the writer had collected a number of specimens in 1912, which were still present in the collection at Río Piedras, and were unquestionably the same as the Puerto Rican species. At the time of their collection, various persons in Triniclad were questioned as to the status of the insect, but they knew it only from its injury to cricket fields, and not as a pest to agriculture.

Due to the close proximity of Trinidad to the continent of South America, it was to be supposed that any continental parasite of the mole-cricket would also be present there, and indeed, the presence of a parasite might be inferred from the supposed scarcity of the host. Furthermore, Trinidad is now so close to Puerto Rico by airplane that the problem of transporting the inferred parasite would be correspondingly simple.

The month of January 1936 was spent by the writer in Trinidad, where, thru the courtesy of Sir Geoffrey Evans, Principal of the Imperial College of Tropical Agriculture at St. Augustine, headquarters for the investigation were maintained at the College. No wasp which might be presumed to be a parasite of Scapteriscus vicinus was collected at this time in any part of the Island, all parts of which were explored, nor was any changa with indication of parasitism noted either at light or in fields being plowed. Indeed, the whole theory of the scarcity of the changa in Trinidad was found to be a misconception. Much of the Island is in virgin forest, or artificial forest of cacao, coffee and grapefruit trees. Furthermore, most of the area under cultivation to sugar-cane is heavy clay soil, entirely unsuited to the mole-cricket. But in the sandy open areas, such as the Savannah at Port-of-Spain, the campus and farm of the Imperial College, and Orange Grove Estate (in sugar-cane), the changa is in general more abundant than in Puerto Rico. And, judging by conditions observed about the lights on the campus, the Surinam toad is even less effective than in Puerto Rico in reducing its numbers.

By a most foriunate combination of circumstances, however, the time spent in Trinidad was productive in indicating where the parasite was to be found and how it might be collected. Mr. A. M. Adamson, formerly of Hawaii and at present Reader in Entomology at the College, possessed a copy of a paper by Mr. F. X. Williams (13) detailing his earliest searches for a parasite of the Hawaiian mole-cricket, in which an extended account, with beautiful illustra- 
tions, was given of his finding Larra americana Saussure, a parasite of Scapteriscus didactylus (Latreille) = vicinus Scudder, in abundance at Belem, Pará, Brazil. Mr. Alan Pickles, Entomologist for the Department of Agriculture of Trinidad and Tobago, stationed at the College, had spent some weeks at Belem only a year or two before, and was of invaluable assistance in furnishing information about this part of Brazil, and more particularly, a letter of introduction to Dr. G. Hagemann, Zoölogist of the Museu Paraense Emilio Goeldi at Belem.

The official restrictions on the activities of foreign scientists (presumably directed primarily against pseudo-scientists and slippery crooks engaged in expeditions "Exploring for Profit") in Brazil at the present time are most strict, but due to Dr. Hagemann's efforts, an official permit to conduct investigations and to ship the parasites was promptly obtained. It should not be imagined, because of the reluctant and jittery attitude of official Brazil towards foreign scientists, that this in any way reflects the actual sentiments of individuals, or at least of those met by the writer during his stays in Belem. From the manager of the local airport of Pan American Airways, Mr. Alberto Soares, and his assistant, Mr. Mario Pereira da Rocha, and the manager of Hotel Grande, Mr. Julio Lima Lages, all three of whom were of invaluable assistance, to the casual passer-by intent on disposing of a snake around his neck, or a turtle on his head, or birds in eages, or numerous school-children volunteering to aid in eatching "borbolêtas", everyone was uniformly most cordial and helpful.

Belem is now only a day's hop by airplane from Trinidad. Early on the first morning after arrival, on the outskirts of the city, along the railroad right-of-way reached by the carline marked "Souza", females of Larra americana were seen exploring changa tunnels in search of their host. A little later in the day, they began to frequent the flowers of Borreria verticillata Meyer (as determined by Mr. José I. Otero, of the Agricultural Experiment Station at Río Piedras), a plant which is common everywhere in Puerto Rico where the changa occurs. It is also so very abundant in Trinidad that the most extensive collections of the larger Hymenoptera were made from its flowers, but included no specimen of Larra. Borreria occurs mostly in fields being fallowed, in waste areas, in dry, unpastured meadows, and especially along railroad tracks, where, being least disturbed, it often grows in clumps as high as one's waist or shoulder. 
In Belem indeed, it is only along the right-of-way of the railroad to Braganza that so many such large clusters are to be found that considerable numbers of Larrid wasps can be collected in a short time.

Mr. Williams had so meticulously recorded his observations in Belem that the wasps could be at once recognized: entirely black except for golden pubescence and bright chestnut red abdomen (fig 3). The field identification by the writer has since been confirmed by Miss Grace A. Sandhouse, from a large number of specimens sent to the U. S. National Museum, of which 85 were Larra americana (Sauss.), 1 Larra altamazonica Williams and 1 Larra pacifica Williams. He did not especially remark on how very quick and active they are when not on the ground, or how extremely wary and difficult to eatch in the net when feeding at Borreria flowers, this being reserved for the writer to discover. He did note, however, that they died within a day or two in captivity, thus the problem of getting them alive to Puerto Rico appeared correspondingly difficult. A trial sending to Trinidad, however, showed that a few at least might survive the trip, and two weeks later the wrster was en route back to Puerto Rico, accompanied by a Wardian cage of local manufacture, in the moist sand at the bottom of which had been thrust the cut ends of Borreria flower stalks, to provide nectar for the 78 wasps of Larra americana which it contained. Leaving Belem early in the morning at the time, one could at the earliest expect to be in San Juan by late the next afternoon. Mr. Francisco Seín, Assistant Entomologist, had managed, with the greatest difficulty, to collect 21 live changas to expose to the tender mercies of the expected parasites-actually only a fraction of a day's supply for the 25 wasps which survived the trip. It seemed much wiser to release the wasps immediately near Punta Las Marías, and hope that they could find a more abundant supply of food for their progeny than could be obtained by our activities. Released towards the beginning of a drought that lasted for three months longer, this was doubtless a vain hope, but at that time the vital importance in the wasp's economy of daily rains could hardly have been surmised. Even if this particular release did not result in the establishment of the parasite of the changa, the trip had at least shown where the parasite might be obtained in numbers, and, with the rapid transportation now possible by airplane, that some wasps would survive the trip for release in Puerto Rico. Apparently nothing more was lacking for a successful introduction than the opportunity to apply on a larger scale the information already obtained. Actually, to get so many wasps alive 


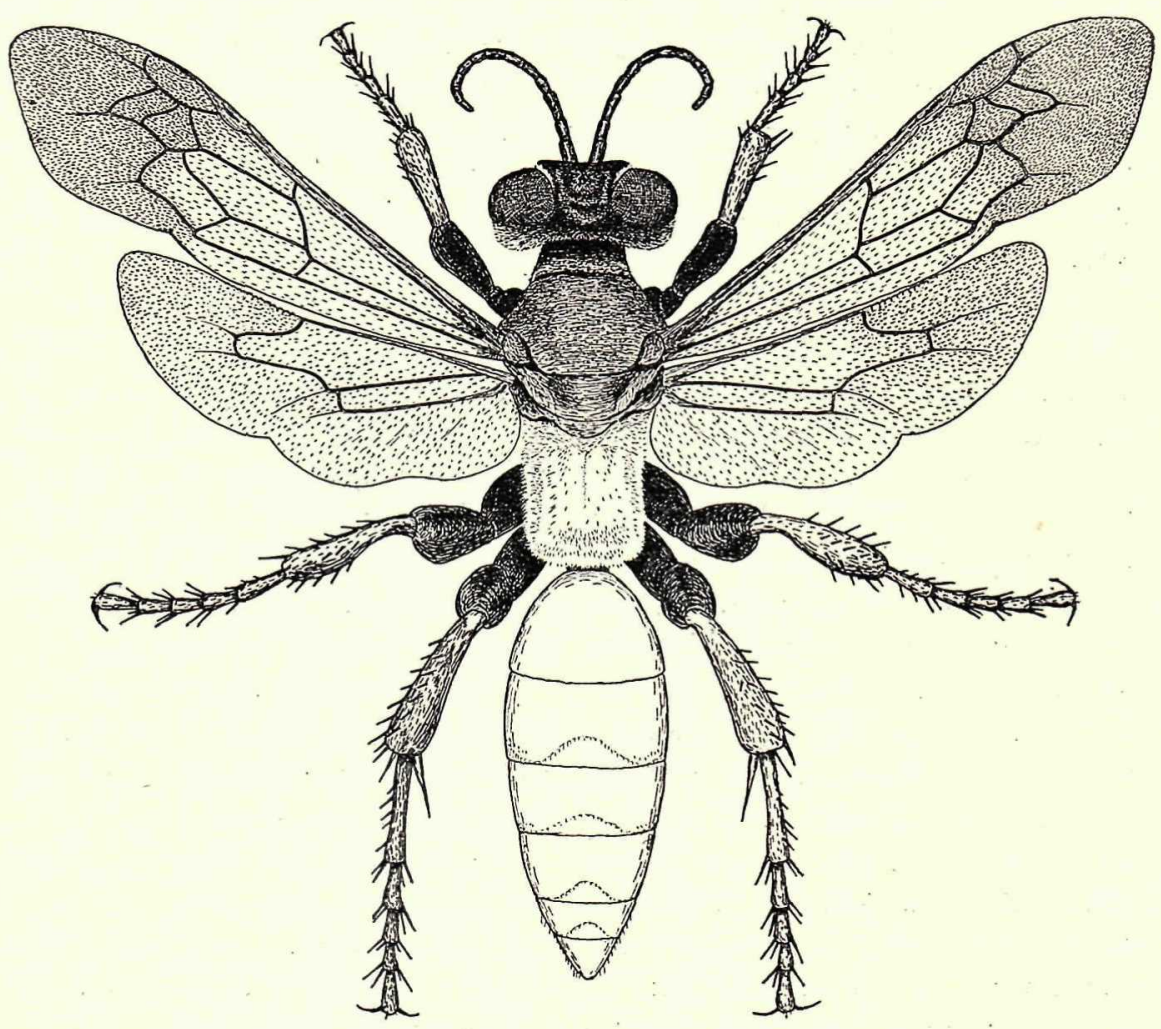

FIG. 3. Adult female wasp of Larra americana Saussure, five times natural size. (Drawn by F. Seín.) 
to Puertio Rico at one time, and at the first attempt, was a most astounding bit of luck, altho in reality a misfortune because i.t gave no indication of the difficulties to be experienced later in attempting its duplication.

Belem is by no means as far south of the Equator as San Juan is north, but for these two localities the time of occurrence of the wet and dry seasons is reversed. The daily rain in the wet season at Belem, or at least at the beginning and towards the end of the wet season there, was admirably described in 1848 by $\mathrm{Mr}$. H. W. Bates in his "The Naturalist on the River Amazons".

"On most days in June and July a heavy shower would fall at some time in the afternoon, producing a most welcome coolness. The approach of the rain-clands was after a uniform fashion very interesting to observe. First, the cool sea-breeze, which commenced to blow about ten o'clock, and which had increased in force with the increasing power of the sun, would flag and finally die away. The heat and electric tension of the atmosphere would then become: almost insupportable. Languor and uneasiness would seize on every one; even the denizens of the forest betraying it by their motions. White clouds would appear in the east and gather into cumuli, with an increasing blackness along their lower portions. The whole eastern horizon would become almost suddenly: black, and this would spread upwards, the sun at length becoming obscured. Then the rush of a mighty wind is heard through the forest, swaying the treetops; a vivid fiash of lightning bursts forth, then a crash of thunder, and down streams the deluging rain. Such storms soon cease, leaving bluish-black motionless clauds in the sky until night. . . The following morning the sun again rises in a clouless sky, and so the cycle is completed."

The female Larra normally has just such a definite cycle of daily activities. The early morning hours are spent on or in the ground in a seareh for changas, forced to the surface of the soil by the soaking rainfal of the previous afternoon. When the ground and the vegetation has been somewhat dried by the morning sun, and especially if she has succeeded in depositing one, or two, or even three eggs of as many changas and the stimulus for further search for a: host for her progeny has disappeared, she then begins to frequent the flowers from which she obtains nectar. The wasps feed only during the hottest hours of the most intense mid-day sunshine, and even when the usual rain does not occur in the afternoon, rarely are to be rnoted feeding very long after mid-day. The passage of a clowd over the sum almost instantly stops their feeding activities, which are not resumed again from rest in the depths of a thicket of Barreria and other weeds until it is again shining brightly. What the wasps do during rain and at night can not be asserted with certainty = those in captivity mostly rested quietly on vegetation or 
on the sides of the container, altho it is possible that some of them may have been burrowing in the sand, or resting quietly in it during part of this time of inactivity.

Mr. Bates' description of the daily shower and the above notes on the activity of Larra apply only to normal weather. The wasps are profoundly affected by any deviation, their eycle of daily activities being predicated exactly to a definite time for the rain. At the time the writer first landed in Belem early in February, the downpour came between 1 and 2 P.M. By the end of the week, the time of this daily storm had advanced to noon, and the practical impossibility of continuing the collection of the wasps by the end of that week was caused by the rain beginning in the middle of the morning. The female Larra feed at flowers, where they can be collected, from $10 \mathrm{~A}$. M. to noon, and if the rain eommences soon after 10, they never reappear at flowers in any eonsiderable numbers that day, even tho later the sun comes out and the vegetation dries off before nightfall. Males may occur on flowers in the afternoon after a shower, and also earlier in the morning, their feeding of course not being disturbed by the necessity for oviposition, which is doubtless the most powerful stimulus determining the activities of the females. It had seemed wise, therefore, to take back to Puerto Rico what wasps had been collected during the second week in February, and 10 return to Belem for more later in the spring, towards the end of the wet season there, and incidentally towards the beginning of the wet season in Puerto Rico.

As it happened, the time of return was properly timed for May, and the wasps were present then in an abundance comparable to, or even greater than that observed in February. They no longer frequented the flowers of Borreria however, but in the same places where collections were made in February, extensive growths of Hyptis atrorubens Poit. (as determined by Mr. Otero), a recumbent plant and not noted before, were now knee-high, and their flowers were greatly preferred by the wasps. Little difficulty had been experienced in keeping the wasps alive for several days in February, but in May few of them lived overnight in captivity, and the bulk of them were dead by the second day. This only duplicated the experience recorded by Mr. Williams, who also was in Belem in May and June. Difficulties also were experienced in making the shipments on time, for the planes from the south three times during the month were two days late in their schedule, due to bad weather in crossing the Andes from Santiago. Out of shipments of 70 or 80 wasps eventually 
despatched from Belem, only one or two wasps would arrive alive in San Juan. The carefully designed container which seemed to embody every factor essential to the comfort and well-being of the wasps en route was promptly discarded in favor of a much larger one, and with little better results until the final shipment. In the meantime, as the end of the wet season approached, the daily rains came later and later in the day, and sometimes not until after darkor not at all. On the possibility that the wasps in captivity might to suffering from lack of humidity, their container received an artifieial rain under the shower-bath as soon as brought from the field, bat with little apparent effect on the mortality.

Incidentally accompanying the rainfall in Belem is a sudden sharp decline in temperature. On the bare possibility that comparable artificial cold might have the effect of keeping the wasps alive, they were placed in an electric refrigerator, and when removed a few hours later all were dead. The manager of the Grande Hotel suggested that he had two refrigerators: the new electrical one for freezing, and the old one using real ice in which the temperature, while considerably cooler than the air outside, never came within $10^{\circ}$ or $20^{\circ}$ of freezing. Another collection of wasps placed in this old "real ice" cooler early in the afternoon and removed at dark had suffered not a single mortality. All the final collections of wasps were accordingly placed in this old-fashioned refrigerator during the hot afternoons.

But now that a practical method had been found for keeping the wasps alive longer, difficulty was experienced in collecting them. The daily rains ceased to be daily, and for each day that there was no rain, the number of wasps which could be collected in the field was a fifth less than on the previous day. At first this was not serious. but when no rains at all came during the second week in June, it became abundantly obvious that no large numbers of wasps would again be collected for the next six months, or until the begimning of the next rainy season. Out of the final shipment of only 18 wasps however, 7 arrived alive in San Juan: the highest survival from any shipment, and comparable to the first in February in the Wardian cage. The wasps in this final shipment had been refrigerated in the aftermoons, and their container placed outdoors at night, including the night preceeding the date of shipment. As there is no stop for the planes north of Belem closer than French Guiana, they usually cover this longest hop at a great height, with the temperatures approximating those of a mountain, and in general, the 
planes are comfortably cool while in motion. The only high temperature experienced for any considerable length of time en route, therefore, is in the late afternoon and early evening at Port-of-Spain, and, with present flying schedules, this is hardly capable of alteration.

For the collection of Larra wasps in the field, the writer has used a small, non-folding, metal frame net presented by Mr. F. W. Urich, for many years Entomologist of the Department of Agriculture of Trinidad and Tobago. For handling live wasps, one has much greater conficlence if wearing a heavy cotton glove on one hand, altho after some experience, one makes sure of the sex of any doubtful individual by letting it attempt to sting, and releasing any unable to prove that they are females. The container at first used in the field was loaned by Mr. K. A. Bartlett, of the Foreign Insect Introduction Division of the U. S. Bureau of Entomology \& Plant Quarantine, but it proved quite unsuitable for the shipment of large wasps. That later designed was manufactured in Brazil by a cabinet-maker recommended by Dr. Hagemann, and measured $3^{\prime \prime} \times 3^{\prime \prime} \times 6^{\prime \prime}$, with a circular opening slightly larger than one's thumb, stoppered with a cork, in one end, thru which the wasps were transferred from the net. To induce them to enter voluntarily, the slide top had eut in it a hinged door, closely screened inside. By opening this door just before the wasp was released from the net, its violent positive phototropism promptly carried it into the container. The bottom third of the container was partitioned off with coarse wire mesh of such size that the wasps could readily pass, if they desired. This third of the container was mostly filled with moist sand, but prevented from coming out by a layer of wet sphagnum moss next to the wire. The cut ends of Borreria or Hyptis flowering stalks were thrust thru this wire mesh into the moist sphagnum and sand, and invariably arrived fresh and unwilted at the end of journey in San Juan, according to the testimony of Mr. Seín. Regardless of their theoretical value, few wasps survived the trip to Puerto Rico in these small containers, and eventually their use was restricted to collection in the field, for which they were well adapted when the wire partition, sand and moss were removed, the interior being loosely filled with wet excellsior and a few flower blossoms. The larger and much simpler shipping cage used for later consignments had only a $5^{\prime \prime} \times 8^{\prime \prime}$ wire screen window in its sliding top. The transferrence of the wasps from the collecting eage to the shipping eage, or to the Wardian cage, was always attended with difficulty, and whatever method was used, before the operation was completed, one invariably wished he เ 
had used some other. At first it was conducted in bed with the mosquito bar tucked in securely on all sides, and later, at night in the bath room from which everything movable had been removed. By sliding back the tops of the two containers so that their openings were opposite, the moist excellsior in which most of the wasps had come to rest could be droped into the shipping cage, but some invariably chose to remain in the field cage, and others became active and escaped where the openings of the two cages did not exactly meet. In such an extremity, a gloved hand might recover those which hid in the folds of the mosquito bar, or which did not at once escape, despite the darkness outside, thru cracks around the door. The bottom of the large shipping cage was covered with a thin layer of moist sand, into which the cut ends of the flower stalks were thrust, and naturally such cages had to be kept right side up, but the superior survival of the wasps in the larger containers much more than justified the trouble of getting the wasps into them, and the greater care that had to be taken of them en route. To prepare for delivery to the plane, several thicknesses of toweling were tied over the screened window, and saturated with water so as to arrive still damp two days later

Mr. Williams has recorded the finding of Larra americana in lesser abundance at more southern localities in Brazil, and of other species of mole-cricket parasites in Equator. Such records are valueless in considering localities from which shipments might more readily be made to Puerto Rico, but at least indicate a wide distribution of such parasites. To determine if Larra americana might not occur at localities even nearer to Puerto Rico than Belem, the writer stopped at Paramaribo, Dutch Guiana, on his return in June 1936. Plants of Borreria were not noted, but quite extensive beds of Hyptis were found at the end of a country road "Charlesburgstraat" in a clearing at the edge of the forest, and feeding on the nectar of their fiowers were females of Larra americana. If the insect ocurs north of the Amazon River, it presumably is present in all suitable sandy regions of tropical South America. The last stop of Pan American Airways on the continent before reaching Trinidad is Georgetown, British Guiana, but the soil here, unlike that around Paramaribo, which is sandy swamp, is mud. Even where it becomes somewhat coarser in texture, neither of the plants frequented by Larra for nectar was noted, altho mole-crickets are present in small numbers in the sandy foreshore outside the seawall, and to a lesser extent in the golf course at Belair, in the outskirts of Georgetown. A day's 
journey into the interior and they become abundant, for Mr. T. A. W. Davis, Forester at the Mazaruni Station, reports them a serious pest in his nurseries, the specimens submitted by him being both Scapteriscus vicinus and Gryllotalpa hexadactyla. Thus, British Guiana is indicated as being no nearer Puerto Rico, from the standpoint of transporiing the wasps, even if they do occur there, than is Belem. Dutch Guiana remains a definite possibility, altho lack of local transportation, and the limited area where Hyptis was noted there, makes Belem still the more desirable locality for the continuance of the attempt at the introduction of a parasite of the changa into Puerto Rico, and the beginning of the rainy season the most favorable time.

Normally, the beginning of the rainy season in Belem is 'sometime in December, usually between Christmas and New Year's Day. In 1936, the first rain, after an unusually long, hot and uninterrupted dry season came on December 28th, the day that the writer left San Juan by plane, so that some wasps were available for collection when he first arrived in Belem. But the rainfall in the first three weeks of January consisted of showers so light as to barely moisten the surface of the ground, so that by the middle of the month only a few Larra were to be seen, and most of these were males. 'The first general and heavy rain was on January 17th, 1937, continuing all that day and night and most of the morning of the 18th, the air being alive with winged termites much of this time, and on the second night tremenduous numbers of adults of the common large black cricket, Grillus assimilis $\mathrm{F}$., invaded the better lighted sections of Belem. The morning of the 19th was bright and clear and the females of Larra suddenly so abundant that one could not keep track of the number collected. Yet out of the 30 or more collected just the day before shipment and sent in the large container by the fast Clipper, making stops only at Paramaribo and Port-of-Spain, and arriving in San Juan before 10 A. M. on the morning of the 21st, only 6 or 7 were alive when received, and only 2 survived to be released at Malesa Sub-Station at Isabela, where the ground was being irrigated every day to bring changas to the surface and Borreria was specially grown to ensure optimum conditions for the wasps. The heavy mortality could not be due to a hot afternoon, for the rain came at 2 P. M. on the 19th, and lasted all night. The container was kept during the night on a window-ledge on the third floor of the Hotel Grande, and not delivered for transportation until the morning of the departure of the plane, at which time, so far as could be determined, it was in good condition. What happens to 
shipments en route is a matter of conjecture, but the spraying of the planes with pyrethrum insecticide just before arrival in San Juan certainly is most unfortunate from the standpoint of keeping the Larra wasps alive. For later shipments, the purser or steward of the plane was personally interviewed in Belem just before the shipment was delivered, and instructions given, in addition to those written on the tag, to pour ice-water on the toweling covering the screen window of the container before landing in Port-of-Spain, to keep the shipment out of the sun after arrival and in the shed at the end of the pier until the following morning, and to keep it in the tail of the plane when the plane is being sprayed at San Juan. So far as can be determined, all the special care had little effect in increasing the survival of the wasps, that of some shipments being most discouragingly low. On the other hand, one shipment of 36 wasps sent by the slow plane from which release could not be made until the following day at Malesa, had 7 wasps alive and active at that time, and the final shipment of 16 wasps, in a container of twice the size of those previously used, with three windows, by the fast plane, had 5 wasps alive for release at Maleza. But the total of 28 wasps received alive out of almost ten times that number collecied is a most disheartening record (see Table), relieved only by the assurance that all of these were females and that they were released where changas were not only abundant, but where the daily irrigation surely made them readily available for attack and oviposition, and where Borreria was present in abundance.

The mortality of Larra was so heavy on the slow planes, with the one most extraordinary exception above noted, that discontinuance of using them was contemplated as soon as the reports began to be received. The slow planes arrive in Trinidad, however, almost as soon as the fast planes do, and as Mr. Pickles was keenly interested in attempting the introduction of Larra in Trinidad, and indeed had attempted to rear the parasite there from the first trial shipment made to him in February, 1936, he was asked to receive shipments of the wasps, either for release or rearing. Just at this time, however, he was in the hospital recovering from an operation, consequently $\mathrm{Mr}$. Adamson received the shipment. Out of 27 females sent from Belem, 7 were alive upon receipt, of which 5 were still alive the following morning, when they were placed in individual tubes or petri dishes and supplied with mole-crickets. Before the last one of these had died, Mr. Adamson had secured 21 eggs, and, at last report, several of the eggs had successfully hatched after 9 days incubation. 
SHIPMENTS OF LARRA AMERICANA, BELEM TO SAN JUAN, 1937

\begin{tabular}{|c|c|c|c|c|c|c|c|c|c|}
\hline $\begin{array}{c}\text { Sending } \\
\text { No. }\end{array}$ & $\begin{array}{l}\text { Type } \\
\text { Cage }\end{array}$ & Weather & $\begin{array}{c}\text { Wasps } \\
\text { Col. }\end{array}$ & $\begin{array}{l}\text { Date } \\
\text { Left }\end{array}$ & $\begin{array}{l}\text { Type } \\
\text { Plane }\end{array}$ & $\begin{array}{l}\text { Date } \\
\text { Arr. }\end{array}$ & $\begin{array}{l}\text { Wasps } \\
\text { Alive }\end{array}$ & $\begin{array}{l}\text { Wasps } \\
\text { Dead }\end{array}$ & $\begin{array}{l}\text { Wasps } \\
\text { Total }\end{array}$ \\
\hline 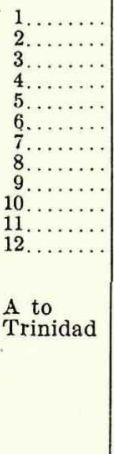 & $\begin{array}{l}\text { Small. } \\
\text { Small. } \\
\text { Small. } \\
\text { Small. } \\
\text { Large. } \\
\text { Large. } \\
\text { Large. } \\
\text { Large. } \\
\text { Large. } \\
\text { Large. } \\
\text { Large. } \\
\text { Extra } \\
\text { large } \\
\text { Large. }\end{array}$ & $\begin{array}{l}\text { Too dry } \\
\text { Too dry } \\
\text { Too dry } \\
\text { Too dry } \\
\text { O.K.... } \\
\text { O.K.... } \\
\text { Cloudy } \\
\text { O.K.... } \\
\text { O.K. ... } \\
\text { O. K... } \\
\text { Cloudy. } \\
\text { Cloudy } \\
\text { O.K... }\end{array}$ & $\begin{array}{c}21 \\
14 \\
17 \\
5 \sigma^{7} 7 \% \\
\text { Many } \\
20 \sigma^{3} 32 \% \\
8 \sigma^{7} 12 \% \\
36 \% \\
29 \% \\
27 \% \\
17 \% \\
17 \% \\
27 \%\end{array}$ & $\begin{array}{l}\text { Jan. } 3 \ldots . \\
\text { Jan. } 6 \ldots . . \\
\text { Jan. } 13 . . \\
\text { Jan. } 17 . . \\
\text { Jan. } 20 . . \\
\text { Jan. } 25 . . \\
\text { Jan. } 27 . . \\
\text { Jan. } 31 . . \\
\text { Feb. } 3 \ldots \\
\text { Feb. } 7 . . \\
\text { Feb. 10.. } \\
\text { Feb. 17.. } \\
\text { Feb. 15.. }\end{array}$ & $\begin{array}{l}\text { Slow.... } \\
\text { Fast.... } \\
\text { Fast.... } \\
\text { Slow... } \\
\text { Fast.... } \\
\text { Slow... } \\
\text { Fast.... } \\
\text { Slow.... } \\
\text { Fast.... } \\
\text { Slow ... } \\
\text { Fast.... } \\
\text { Fast..... } \\
\text { Slow.... }\end{array}$ & $\begin{array}{l}\text { Jan. } 4 \ldots . \\
\text { Jan. } 7 \ldots . . \\
\text { Jan. 14.. } \\
\text { Jan. 18.. } \\
\text { Jan. 21.. } \\
\text { Jan. } 26 . . \\
\text { Jan. 28.. } \\
\text { Feb. 1... } \\
\text { Feb. 4... } \\
\text { Feb. } 8 \ldots . \\
\text { Feb. 11.. } \\
\text { Feb. 18.. } \\
\text { Feb. 15.. }\end{array}$ & $\begin{array}{c}\text { None.... } \\
3 \\
1 \\
\text { None.... } \\
2 \\
2 \\
4 \\
7 \\
2 \\
\text { None.... } \\
2 \\
\\
\quad 5 \\
\\
7,5 \text { on } \\
\text { Feb. } \\
\text { I6th, all } \\
\text { used in } \\
\text { breeding } \\
\text { in labor- } \\
\text { atory }\end{array}$ & $\begin{array}{c}21 \\
15 \\
20 \\
\text { Not Cou } \\
\text { Not Cou } \\
50 \\
21 \\
29 \\
27 \\
27 \\
15 \\
11 \\
20\end{array}$ & $\begin{array}{l}21 \\
18 \\
21 \\
\text { ted } \\
\text { ted } \\
52 \\
25 \\
36 \\
29 \\
27 \\
17 \\
16 \\
27\end{array}$ \\
\hline
\end{tabular}

Except for the one collection of January 19th, 1937, on no other day during January and February of this year were so many wasps collected as on many days during May 1936. Possibly this may have been due to the effect of intensity of the dry season of 1936, or it may merely. be due to the fact that no males were collected after the rains had started in 1937, and the wasps were in reality quite as abundant as previously. While the total number collected during a day often was almost as high as in May, the effort and time spent in the field was much greater, and when the daily rains did not come until 2 or 3 , or sometimes 4 P. M., the wasps rarely appeared in any numbers during the morning, the bulk of the collection of females being made from noon up to within a few minutes before the breaking of the storm. Few mornings were of uninterrupted sunshine, scattered clouds beginning to appear often just at about the time when the wasps were to be expected, and increasing in number and density as the day advanced so that the wasps found but few intervals in which to fly about and feed in full sunshine. Apparently they can not see as well when the day is eloudy, and certainly they are not as active, wary and hard to eatch, even tho fewer of them are available to be caught.

All collections were brought to a sudden termination in Belem by the middle of February by the sudden concerted aetivity of the municipal authorities in cleaning up the city after carnaval, which consisted in cutting the weeds, not only on the streets in the city, but far out beyond the city line along the railroad tracks where the bulk of the collections were being made. The mowing dowr of these 
dense thickets of Borreria did not serve to concentrate the wasps on the few clumps left, for beyond the built-up part of the city, the forest surrounds it on all sides not bounded by the rivers. There are no waste lands or abandoned areas; clearings or burned-over areas in the forest are planted to yuca, or grow up so rapidly to high second growth that Borreria has no chance to become established, and in reality the only favorable places for it are along the too-wide roads of the outskirts of Belem, or along the railroad track. The weather also at this time was rapidly becoming less favorable to Larra, entire days being cloudy and misty, interrupted, not by sunshine, but by showers, so that even while good collecting areas were still available, the number of wasps that could be collected was rapidly diminishing.

In normal years, Dutch Guiana has a short rainy season during December and January, so that growths of Hyptis should be at their height in February, and Larrid wasps abundant. During the one week spent there in February 1937, two wasps were seen, for there had been no short rainy season this year. Hyptis growth was still recumbent, but by riding on a bicycle to the end of every road around Paramaribo, its areas of abundance could be located and plotted, for use at times when wasp collections might be made there.

The dishearteningly small number of Larra surviving the journey from Belem to San Juan in January and February 1937 seemed to indicate the desirability of finding some closer point of collection, the shorter journey from which might enable more of the wasps to survive. To be sure, Paramaribo, Dutch Guiana, is considerably nearer San Juan, but the airport is so far from points where Larra is found that no collections would be possible on the day of shipment. Since Georgetown, British Guiana, is unsuitable, the other points in South America which might be considered are the airports of Venezuela. The one nearest to Trinidad is the oil-field at Caripito, the next is Guanta, the port of Barcelona, both with such frequent airplane service that wasps collected at either point would reach San Juan by the next morning. A personal inspection of Guanta and Barcelona in April 1937 immediately indicated their unsuitability, the area in the vicinity of Guanta being a desert, and Barcelona is hours away by automobile. The presence of Borreria verticillata along the banks of the river beside Barcelona might indicate the possible presence of Larra during rainy weather, but at the time the survey was made there had been no rain for some weeks, and the presence of adults was not to be expected. Caripito is a clearing in the midst of virgin forest of the Orinoco delta region, rainfall is normally 
considerably more abundant than at Barcelona, and Borreria verticillata grows in abundance on the sandy soil of the landing field of the airport. April, however, is a month of drought for Caripito, and the only hope of collecting Larra was to return in the summer, when the greatest abundance of rainfall is to be expected.

Mr. Luis F. Martorell spent part of August 1937 at Caripito, but despite the apparent suitability of conditions, he collected ondy a few small Larra americana (as determined by Miss Grace Sandhouse), the wasps heing so scarce that making shipments of live adults to San Juan was out of the question at that time. His collections and the definite determination of the specimens, however, establishes the record of Larra for Caripito, and its scarcity at the time he was there by no means proves that it might not be abundant in other years when total rainfall is more abundant than it was in 1936-37. Caripito remains a possibility to be further investigated if others fail.

The doubtful record of the presence of the changa in Haiti was assumed to refer to Gryllotalpa hexadactyla Perty, when the Cuban mole-cricket was definitely determined to be that species. In the summer of 1937, Mr. André Audant, Entomologist in Haiti for the Service National de la Production Agricole et de l'Enseignment Rural, sent a specimen of a mole-cricket collected by a student to the U. S. National Museum for determination. Mr. A. B. Gurney, the specialist in Orthoptera there, identified it as Scapteriscus vicinus Scudder, and Mr. Audant, knowing of our great interest in this insect, promptly reported the determination to us. To determine whether the scarcity of the Puerto Rican mole-cricket in Haiti was due to control by a parasite, two weeks in November and December 1937 were spent there. In Mr. Audant's automobile, nothing of interest was noted driving northwest from Port-au-Prince to St. Marc and in the valley of the Artibonite, but on the second day going west towards Petit Goave, three live changas were collected in a sandbar in the bed of a stream. This is the first definite locality collection of Scapteriscus vicinus in Haiti.

The greater part of Haiti is mountainous in character, the central plain of the Cul-de-Sac being heavy clay, and most of the stream deltas consist of loose rocks and bowlders, succeeded immediately by clay, with no intermediate sandy area where the changa might find conditions suitable for its existence. Thus the sandy stream bed at Petit Goave, where these changas were found, in reality is quite exceptional for Haiti. 
An exceptionally complete herbarium of the plants of Haiti is to be found at the Damien office and school of agriculture, having been assembled by Dr. Erik Ekman of Uppsala, Sweden. He collected specimens of the two plants at the flowers of which Larra americana is most commonly found in Brazil: Hyptis atrorubens between Port Margot and Bayeux on the north coast, and Borreria verticillata at Morne Brouet, south of Kenseoff, at an elevation of 1,600 meters. As Ekman was more likely to collect from relatively inaccessible localities, rather than in those more readily reached by automobile, to search for Borreria in the region where he found it required several days of travel afoot. The mountains between Portau-Prince and Kenseoff were tramped over one day, and three clays were spent at Kenscoff, and on one of the mountains south of Kenscoff, at an elevation of possibly 1,700 meters, large clumps of an undetermined species of Borreria or Mitracarpus were found. They were growing mingled with such temperate zone plants as blackberry, mullein, wild carrot, narrow-leaved plantain, dandelion, St. Johnswort, chick-weed and white clover. Hours were spent watching them during the middle of the day in bright sunshine, but no wasp even remotely resembling Larra was noted. Considering the low temperature (except in full sunshine), and the soil, which is a heavy clay, the absence of Larra is hardly surprising, and further search in the Kenscoff mountain region was discontinued.

The only sandy beaches in Haiti near Port-au-Prince, aside from those previously investigated towards St. Marc, are on the southern coast of the southern peninsula. A one day trip to Jacmel was most disappointing in its results, the only sandy beach being just at the city, and used for a public dump. A two day trip to Cayes showed little more of tangible value, for the beaches between Aquin, St. Louis du Sud and Cayes are comparatively narrow, and back of them the soil is clay, with bare rocks or steep mountains rising close behind. The sand bar across the mouth of the river at Cayes is extensive, but neither Hyptis nor Borreria grew there. No trace of the changa was noted, altho rain of the day of going would have made its presence visible the next day coming back if it had been at all abundant. Thus the net result of three days travel over rough roads was entirely negative: no changa and no plant on the flowers of which Larra might be expected to occur, altho conditions of temperature and rainfall, and soil for limited areas, would appear to be somewhat more favorable than in the region nearer Port-au-Prince. 
While the period spent in Haiti was too short to eliminate all possibilities, it would appear that in the area which may be reached by automobile in a day from Port-au-Prince, the changa occurs in very limited regions, and the plants at which Larra is found in Brazil do not occur at all. The scarcity of the changa is thus presumably due to the limited environment in which it can occur, and not due to the presence of a specific parasite.

The possibilities of collecting Larra at points nearer by airplane to San Juan having been temporarily or entirely eliminated, refinements and improvements in methods and technique from Belem still remained to be tried, and in the middle of January 1938, Mr. Luis F. Mariorell proceeded to Brazil. During the few days less than a month that he was there, six shipments of Larra were made, and one was brought with him, small in number of Larra adults as compared with those of previous years, due to unfavorable and abnormal weather in Belem, but otherwise the most successful of any yet made. The weather during January and February 1938 was also most abnormal in Puerto Rico, being especially favorable for the introduction, and releases could thus be made less than half an hour from the San Juan airport, in an extensive sandy area to the south of the Laguna de San José which is most nearly comparable in Puerto Rico to the region from which Larra comes in Brazil. The releases were made beside an acre previously in cultivation which is now almost a solid mat of Hyptis atrorubens, while high plants of Borreria are numerous in near-by pastures and areas not in cultivation. During the time that the shipments were being received, the weather of this region, while not exactly the same as Belem at this time of year with rains early in the afternoon, was sufficiently similar in essentials, for in Puerto Rico the rains came nearly every night or early morning, with the middle of the day bright and clear. The exceptional weather in Puerto Rico this winter is a very important factor favoring the success of the introduction.

In regions where mole-crickets are abundant in Trinidad and Puerto Rico, many of them will come to light on rainy nights, but none was thus noted by the writer at Belem during the months spent there. Mr. Martorell was determined to obtain at least a few specimens, and going out at night with a flashlight and a boy to dig, succeeded in obtaining several on the first attempt. The boy subsequently obtained many more, for which he was paid at the rate of 3 cents for each specimen. Mr. F. X. Williams has related how he induced Larra wasps to attack and parasitize mole-crickets 
in captivity, and Mr. Martorell, using similar methods of introducing the wasp into a small tube with the changa, and shaking them up together if the wasp at first showed no interest, succeeded in obtaining many artịicially parasitized mole-crickets. In all shipments except the first two, such parasitized changas were sent to San Juan with the wasps, and one shipment consisted only of such Larra in the egg stage. Some of the changas died en route, but over three-fourths of them survived the journey and the close confinement, and most of these were released upon arrival. Of those which were retained in the laboratory, eggs which had been laid previous to January 26th hatched within a few days after receipt, and had grown to full sized maggots by two weeks later (February 141h), the air temperature recorded beside them during this period varying from $72^{\circ}$ to $78^{\circ} \mathrm{F}$. Only one maggot, however, succeeded in forming a cocoon, and even this one died before transforming to adult. The weight of cocoon and contents was $.3145 \mathrm{gr}$., but this is not net, as it includes grains of sand stuck in the viscous dark brown plastic of which it was composed, which could not be separated out.

The live weight of a changa is .78 gr., its air-dry (dead) weight $.287 \mathrm{gr}$, and subtracting from this the heavily chitinized remains not available for consumption by the parasitic maggot which weighed .077 gr., gives $.21 \mathrm{gr}$. as the net air-dry weight of the food eaten by Larra in its parasitic stage. The air-dry weight of large Larra females is $.0524 \mathrm{gr}$., and of Larra males .022 gr., thus it would appear that the food eaten by the Larra may be as little as four times for females, or as much as ten times for males, as the weight of the aduit which it becomes. It is much more likely that parasites on the largest changas become females, while smaller changas or large nymphs furnish only food sufficient for the development of males, and the efficiency in the consumption of food by the larval Larra is substantially that previously determined by the writer for other parasitic insects (16).

In keeping the changas in individual cans with sand and corn, no mortality of the host is experienced after those injured in transit have died, but eggs or maggots are easily killed or dislodged in attempting to examine the active changas for their presence. Thus, only the parasitized changas of the first shipment were retained in captivity, mostly to determine the rate of development of the parasite, and all subsequent parasitized mole-crickets were released in the field. Of the total of 121 parasitized changas sent from Belem, 95 arrived in San Juan alive, and of these, 79 were released in the field at the same time as the wasps. 


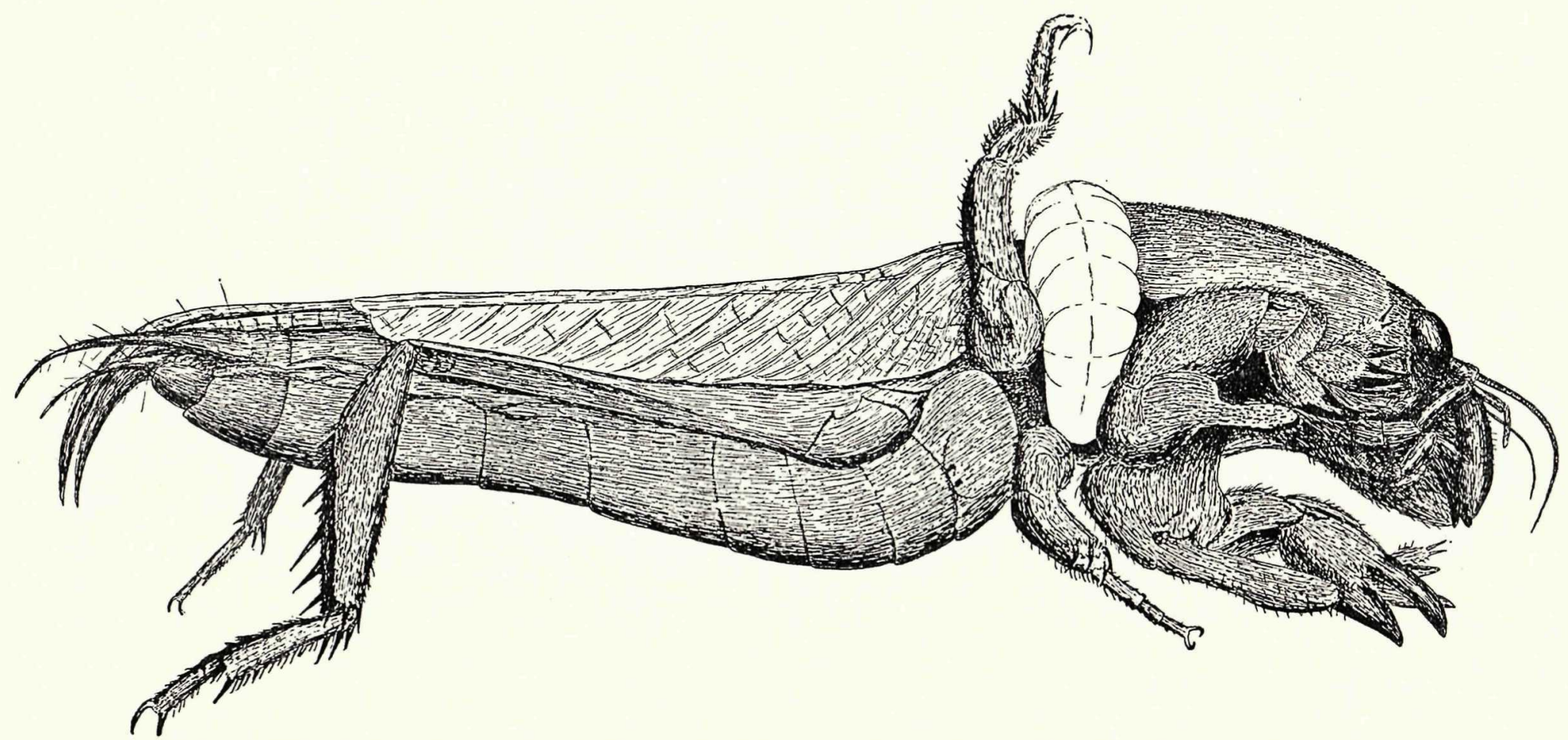

FIG. 4. Maggot of Larra americana feeding on the juices of a "changa" killed by it. (Drawn by F. Sein.) 
Quite aside from the number of Larra thus introduced in the egg stage, the presence of the parasitized changas in the box with the wasps had a most surprising effect in greatly reducing their mortality. In the first two shipments made without changas accompanying, only one wasp arrived in San Juan alive; of the succeeding shipments which had a screened box or ean of parasitized changas, the first contained 11 live wasps, 1 weak and 6 dead, the second contained 18 live wasps and only 1 dead, the third had 9 live wasps and only 2 crushed under the box of earth and changas, while the final shipment brought by Mr. Martorell in person, but delayed en route an additional day at Trinidad, had 7 live wasps and 4 dead. This is so much better than any previous series of shipments as to indicate that the presence of live changas is quite essential for keeping the wasps alive en route, and will of course be used in all future shipments. It appears to be the key to the problem: the solution of how to get the wasps alive from Belem to San Juan. The total number of wasps sent by Mr. Martorell this year was 81, of which 35 arrived dead and 46 alive, as compared with 262 shiped last year, but of which only 28 arrived alive. The difference in the total number indicates the much less favorable weather in Belem for making the collections, while the much larger proportion of wasps arriving alive shows the more successful method of shipment accompanied by changas. The total of only the shipments accompanied by changas is even more clearly indicative of the success of this method: 59 wasps sent, 45 arrived alive, with only 14 dead.

\section{Bibliography}

1. Bates, H. W. "The Naturalist on the River Amazons." pp. 407 , illus., 3 maps. No. 446 of "Everyman's Library" London and New York, 1910.

2. Bunker, F. H. "El Cultivo del Tabaco en Puerto Rico." Circ. Fomento No. 10, Dept. Agr. y Trab., pp. 73, fig. 20. San Juan, 1926.

3. Busck, Aug. "Notes on a Brief Trip to Porto Rico in January and February, 1889." in U. S. Dept. Agr. Bur. Ent. Bull. No. 22 (N. S.), pp. 88-93. Washington, D. C., 1900.

4. Cardín, P. "A Probable Parasite of Scapteriscus didactylus in Cuba." Jour. Ee. Ent., 6(3):330-331. Geneva, N. Y., June 1913. 
5. Cook, Mel. T. "Primer Informe Anual de la Estación Central Agronómica, Informe del Dept. de Pat. Vegt." p. 198. Santiago de las Vegas, Cuba, 1906.

6. Crossman, S. S. and Wolcott, G. N. "Control of the Changa." Circ. No. 6, Insular Exp. Station, Río Piedras, P. R., pp. 5. San Juan, 1915.

7. Dexter, R. R. "The Food Habits of the Imported Toad, Bufo marinus, in the Sugar-Cane Sections of Porto Rico." Bull. No. 74, International Society Sugar Cane Technologists, pp. 6, tab. 11, ref. 6. Fourth Congress, San Juan, March 1-16, 1932.

8. Ledru, A. P. "Viaje a la Isla de Puerto Rico en el Año 1797.' Paris, 1810.

9. Scaramuzza, L. C. "La Identidad del 'Berraquito de la Tierra' de Cuba." Mem. Soc. Cubana Hist. Nat., $10(1): 21-24$. Habana, 1936.

10. Wetmore, Alex. "Birds of Porto Rico." Bull. No. 15, Bd. Comm. Agr., also Bull. No. 326, U. S. Dept. Agr. (Professional Paper), pp. 140, pl. 10. Washington, D. C., March 24, 1916.

11. Williams, F. X. "Philippine Wasp Studies, Part 2, Descriptions of New Species and Life History Studies.' Bull. No. 14, Entomological Series, Expt. Sta. H.S.P.A., pp. 19-186, fig. 106, many ref. Honolulu, Hawaii, December 1919.

12. "The Insect and other Invertebrates of $\mathrm{Ha}$ waiian Sugar Cane Fields." pp. 400, fig. 190, pl. 41. Expt. Sta. H. S. P. A., Honolulu, Hawaii, 1931.

13.

"Studies in Tropical Wasps-Their Hosts and Associates (with Descriptions of New Species)." Bull. No. 19, Ent. Series, Expt. Sta., H. S. P. A., pp. 179, fig. 16, pl. 34 . Honolulu, Hawaii, January 1928.

14. Wolcott, G. N. "The Food of Porto Rican Lizards." Dept. Agr. P. R., 7(4) : 5-37, ref. 8. San Juan, 1924.

15.

"What the Giant Surinam Toad, Bufo marinus L., is eating now in Puerto Rico." Jour. Agr. Univ. P. R., 21(1) : 79-84, San Juan, 1937.

16. - . "On the Amount of the Food Eaten by Insects." Jour. Dept. Agr. P. R., 9(1) : 47-58, ref. 6. San Juan, January 1925. 